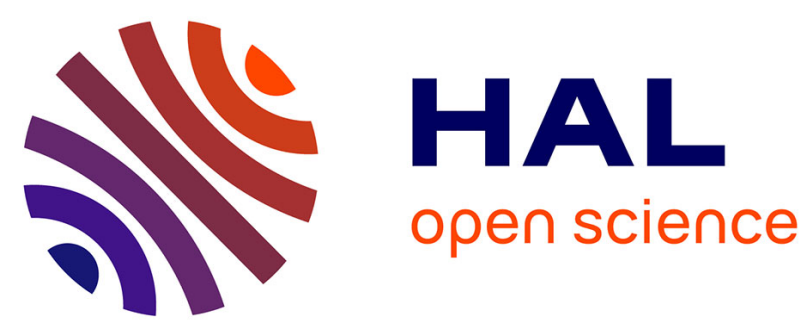

\title{
Identification of genes involved in growth inhibition of breast cancer cells transduced with estrogen receptor.
}

Anne Licznar, Simona Caporali, Annick Lucas, Alessandro Weisz, Françoise Vignon, Gwendal Lazennec

\section{- To cite this version:}

Anne Licznar, Simona Caporali, Annick Lucas, Alessandro Weisz, Françoise Vignon, et al.. Identification of genes involved in growth inhibition of breast cancer cells transduced with estrogen receptor.. FEBS Letters, 2003, 553 (3), pp.445-50. inserm-00143969

\section{HAL Id: inserm-00143969 https://www.hal.inserm.fr/inserm-00143969}

Submitted on 30 Apr 2007

HAL is a multi-disciplinary open access archive for the deposit and dissemination of scientific research documents, whether they are published or not. The documents may come from teaching and research institutions in France or abroad, or from public or private research centers.
L'archive ouverte pluridisciplinaire HAL, est destinée au dépôt et à la diffusion de documents scientifiques de niveau recherche, publiés ou non, émanant des établissements d'enseignement et de recherche français ou étrangers, des laboratoires publics ou privés. 


\title{
Identification of genes involved in growth inhibition of breast cancer cells transduced with estrogen receptor
}

\author{
Anne Licznar, Simona Caporali*, Annick Lucas, Alessandro Weisz*, Françoise Vignon \\ and Gwendal Lazennec ${ }^{\mathbb{T}}$
}

\author{
INSERM U540 "Molecular and Cellular Endocrinology of Cancers", \\ 60, rue de Navacelles - 34090 Montpellier, France \\ * Dipartimento di Patologia generale, Seconda Università degli Studi di Napoli, \\ Vico L. De Crecchio 7, 80138 Napoli, Italy
}

licznar@montp.inserm.fr / Phone: 33467043778 / Fax: 33467540598

s.caporali@idi.it / Phone: 390666464706 / Fax: 390666464705

lucas@ montp.inserm.fr / Phone: 33467043778 / Fax: 33467540598

alessandro.weisz@unina2.it / Phone: 39081 566-5702 / Fax: 39081 566-5702

vignon@montp.inserm.fr / Phone: 33467043760 / Fax: 33467540598

\begin{abstract}
Estrogen receptor alpha (ER $\alpha)$-negative breast cancer cells display an aggressive phenotype. We previously showed that adenoviral expression of ER $\alpha$ in ER-negative breast cancer cells leads to an estrogen-dependent down regulation of the proliferation, which could be of interest to control the growth of such cells. In this study, we observed an increase in protein levels of p21 and p27 CDKIs, whereas pRb phosphorylation strongly decreased. Flow cytometry experiments showed that cells were blocked in G2/M-phase. By using cDNA macroarrays, we identified a novel collection of genes regulated by liganded-ER $\alpha$ potentially regulating cell cycle, apoptosis, cell signalling, stress response and DNA-repair.
\end{abstract}

Key words: estrogen, receptor, proliferation, cDNA array

${ }^{\mathbb{I}}$ Corresponding Author:

Dr Gwendal Lazennec

INSERM U540 " Molecular and Cellular Endocrinology of Cancers ", 60, rue de Navacelles - 34090 Montpellier, France

Tel: (33) 4670430 84; Fax: (33) 467043084

E-mail: lazennec@montp.inserm.fr 


\section{Introduction}

Breast cancer is one of the leading causes of premature death in women in occidental countries [1]. Increased lifetime exposure to estrogens is an established risk factor for development of breast cancer. Estrogen action is mediated by two estrogen receptors $E R \alpha$ and ER $\beta$. ER $\beta$ is poorly expressed in breast tumors [2]. A high percentage of early stage mammary tumors are estrogen receptor $\alpha(\mathrm{ER} \alpha)$-positive and about $50 \%$ of these patients respond to anti-estrogen or endocrine therapy [3,4]. Later stages of breast cancer are more aggressive and refractory to most therapies and this correlates with the ER $\alpha$-negative phenotype of these tumors [5]. ER $\alpha$-positive tumor cells are poorly metastatic in nude mice when compared with some ER $\alpha$-negative breast cancer cells [6]. In patients, ER $\alpha$-positive tumors are more differentiated and have lower metastatic potential than ER $\alpha$-negative tumors [7], suggesting a protective role of the ER $\alpha$ in tumor progression. Introduction of ER $\alpha$ into ER-negative breast cancer cells has been thought to provide a rational basis for converting anti-estrogen resistant cells to hormonal manipulation. However, in contrast to the expected stimulated proliferation of ER-positive cells, the restoration of $\mathrm{ER} \alpha$ expression in ER-negative breast cancer cells leads to a ligand-dependent inhibition of proliferation as shown by numerous studies [8-11]. The mechanisms underlying this phenomenon have been poorly investigated and could be of great interest to control the proliferation of these aggressive types of tumor cells. The goal of this study was to discerne events responsible for the ligand-dependent inhibition of breast cancer cells expressing exogenously ER $\alpha$ by analysing possible cell cycle regulation and modulation of gene expression.

\section{Materials and Methods}

\subsection{Recombinant adenovirus construction and propagation.}

The complete coding sequence of wild-type hER $\alpha$ cDNA was subcloned in BamHI site of the pACsk12CMV5 shuttle vector. To obtain recombinant viruses, permissive HEK-293 cells (human embryonic kidney cells) were cotransfected with the backbone or recombinant pACsk12CMV5-hER plasmid and with pJM17, which contains the remainder of the adenoviral genome as previously described [11]. In vivo recombination of the plasmids generates 
infectious viral particles Ad5 (backbone virus) and Ad-hER $\alpha$ ). Titered virus stocks were used to infect MDA-MB-231 cells.

\subsection{Cell Culture and infection}

MDA-MB-231 cells were maintained in Leibowitz L-15 medium supplemented with $10 \%$ fetal calf serum (FCS) and gentamycin. To wean the cells off steroids, they were cultured in phenol red-free DMEM/F12 supplemented with 10\% CDFCS (charcoal dextran-treated FCS) for 4 days. For infection, cells were cultured in the same medium and infected with Ad5 or Ad-hER $\alpha$ viruses at a multiplicity of infection (MOI) of 100.

\subsection{Whole cell extract preparation and western blot.}

Cell extracts were prepared in NP40 buffer [50mM Tris- $\mathrm{HCl} \mathrm{pH} 8.0,150 \mathrm{mM} \mathrm{NaCl}, 1 \%$ NP40, $10 \mu \mathrm{M}$ Sodium fluoride, $0.1 \mathrm{mM}$ Sodium orthovanadate, $1 \mathrm{mM}$ phenylmethyl sulphonyl fluoride (PMSF), $10 \mu \mathrm{g} / \mathrm{ml}$ aprotinin, leupeptin, pepstatin A and 20nM okadaic acid]. Cells were washed twice in ice-cold PBS, scraped in ice-cold NP40 buffer and lysated for $10 \mathrm{~min}$. Cell lysates were cleared by 15 minutes centrifugation at $4^{\circ} \mathrm{C}$, protein content in the supernatant was assayed by Bradford Protein Assay (BIORAD). The cell extracts were diluted 1:1 in 2X Laemmly sample buffer, followed by boiling for $5 \mathrm{~min}$. Equal amounts of protein were loaded and separated for SDS/PAGE gel. Proteins were transferred to cellulose nitrate filters (Schleicher and Schuell, Germany) and blocked 30 min at $37^{\circ} \mathrm{C}$ in $5 \%$ non fat milk in TBST (TBS with $0.1 \%$ Tween 20 ). Membranes were incubated with the primary antibody for $1 \mathrm{~h}$ at RT in TBST. The primary antibodies were: cdc2 (Ab-4; NeoMarkers)1:500; cdk2 (Transduction Laboratories)1:1000; Cyc A (BF683; Santa Cruz Biotechnology) 1:200; Cyc B1 (GNS1; Santa Cruz Biotechnology)1:200; Cyc D1 (CDS6, Sigma)1:200; Cyc D3 (Transduction Laboratories) 1:1000; Cyc E (M20; Santa Cruz Biotechnology)1:200; ER $\alpha$ (ER-311; [12]) 1:1000; ERK (K23; Santa Cruz Biotechnology) 100 $\mu \mathrm{g} / \mathrm{ml}$; Rb (IF8; Santa Cruz Biotechnology)1:500; p21 ${ }^{\text {CIP-1 }}$ (L17; Santa Cruz Biotechnology) 1:100; $2^{\mathrm{kIP}-1}$ (C19; Santa Cruz Biotechnology) 1:100. After washing, horseradish peroxidase- 
linked secondary antibodies (Amersham-Pharmacia) were added and target protein bands have been detected using ECL (Amersham-Pharmacia).

\subsection{Flow Cytometry Experiments.}

To analyze the effects of recombinant viruses on the cell cycle, MCF-7 cells were infected with the adenoviral vectors, and cells were fixed in Ethanol $75 \%$ for 2 min. Fixed cells were then stained with PBS containing $40 \mu \mathrm{g} / \mathrm{ml}$ propidium iodide and $100 \mu \mathrm{g} / \mathrm{ml}$ RNAse. After a $30 \mathrm{~min}$ incubation at $37^{\circ} \mathrm{C}$, analysis was performed on an Epics-XL flow cytometer (Beckman Coulter, Fullerton, CA).

\subsection{RNA extraction, Northern blot and cDNA Microarrays.}

Total RNA was isolated with TRIzol reagent (Invitrogen) as described by the manufacturer. RNA quantity was checked photometrically by absorption at $260 \mathrm{~nm}$ and quality was determined by examination of the $28 \mathrm{~S}$ and $18 \mathrm{~S}$ rRNA bands in ethidium bromide-stained agarose gels. After two phenol/chloroform extractions, RNA was precipitated. To remove genomic DNA contamination, RNA was treated with ribonuclease (RNase)-free deoxyribonuclease (DNase) I (Clontech, Palo Alto, CA), and was then dissolved in RNase-free $\mathrm{H} 2 \mathrm{O}$ and stored at $-80^{\circ} \mathrm{C}$ until analysis. For Northern blot analysis, $20 \mu \mathrm{g}$ RNA were electrophoresed and then hybridized with the different probes. The Atlas human macroarray (7740-1: 588 genes) was purchased from Clontech. For cDNA probes, $5 \mu \mathrm{g}$ of total RNA from MDA-MB-231 infected with Ad-hER $\alpha$ and treated or not for $24 \mathrm{~h}$ with E2 $(10-8 \mathrm{M})$ were used. The Atlas arrays were then hybridized with the probes according to manufacturer instructions. Array images were analyzed using Atlas Image 2.0 software (Clontech, Palo Alto).

\section{Results}

\subsection{Growth inhibition involves G2/M transition blockage}

We have previously showed that exogenous expression of ER $\alpha$ in MDA-MB-231 ER-negative breast cancer leads to growth inhibition in the presence of estradiol [11]. To better characterize 
the phenomenon involved in growth inhibition, we performed flow cytometry experiments on cells which had been treated for different times with estradiol (Fig. 1). Cell cycle distribution of Ad5 infected remained unchanged upon estrogen treatment. On the other hand, Ad-hER $\alpha$ infected cells cell cycle distribution was strongly affected. The proportion of ER $\alpha$ cells in $S$ phase strongly diminished upon treatment with estradiol (27 to 16\%), whereas the proportion of cells in G1 phase was constant and the proportion of cells in G2/M phase increased from 13 to $17 \%$. Importantly, we should also notice the presence of a sub-G1 peak which is characteristic of cells undergoing apoptosis (Fig. 1).

\subsection{Analysis of cell cycle modulators expression}

To dissect the mechanisms underlying this inhibition of proliferation, we analyzed at the protein level the expression of a collection of known cell cycle modulators. A time course of estradiol treatment was performed on Ad5 or Ad-hER $\alpha$ infected cells and whole cell extracts were analyzed by western blot (Fig. 2). ER $\alpha$ was only detected in Ad-hER $\alpha$ infected cells. Of particular note is the appearance of a slower migrating band upon estradiol treatment which could correspond to a phosphorylated form of ER $\alpha$. ERK phosphorylation did not show any modification whereas $\mathrm{pRb}$ phosphorylation was strongly diminished. Cyclins D1 and E were upregulated in a ligand-independent manner, whereas cyclin A and D3 expression remained constant. CDKI p21 and p27 showed a nice up-regulation following estradiol treatment. Finally, cdc2 and cdk2 levels were stable. In summary, these data show a complex regulation of cyclins and CDKI involved in G1 to S phase transition.

\subsection{Liganded-ER $\alpha$ induces a complex pattern of gene regulation}

To have a better sense of the mechanisms underlying the growth inhibitory effect of ligandedER $\alpha$, we compared the expression of 588 genes between ER $\alpha$-infected cells treated or not with E2, by using cDNA macroarrays. A total of 12 genes were up-regulated by E2 (Table 1), whereas 27 genes were down-regulated by E2 (Table 2). The genes identified were potentially involved in oncogenesis or tumor suppression (RAF, c-myc, c-fms, c-jun, Fra-1, Axl), cell cycle 
(cyclin G2, TOB, p21, STK-1), apoptosis (BNIP3, Gadd45, Gadd153, DAP-3), transcription (TAFII31, ATF-2, ATF-4, HIP116, CNBP, Y box), cell signalling (TGF $\alpha$, G-CSF, Thrombomodulin, BMP-4, IL1 $\beta$, Thrombin receptor, Macmarcks, CTGF), cell adhesion (Integrin $\alpha 3$ chain, integrin $\beta 1$ subunit), stress response (HSP60, Glutathione reductase, Glutathione peroxidase), DNA synthesis and repair (TopoII $\alpha$, HHR23A, HHR23B, DNA-PK, DBI). This suggests that exogenous expression of ER $\alpha$ and subsequent activation by E2 leads to major changes in gene regulation of the cells affecting multiple aspects of cell life.

\subsection{Confirmation of the regulations by northern blot}

To confirm the regulations identified by cDNA array screening, we analyzed the expression of 13 genes by northern blot (Fig. 3). pS2 gene (not present on the array) was used as a positive control of estrogen regulation and it was induced only in Ad-ER $\alpha$ infected cells treated with E2. We observed that the levels of Fra-1, Gadd45, DAP-3 and TopoII $\alpha$ and DNA-PK were effectively down-regulated by liganded-ER $\alpha$, whereas cyclin G2, G-CSF, IL1 $\beta$, Macmarcks, BNIP3, p21/CIP-1 and TGF $\alpha$ levels were up-regulated, which validates our screen.

\section{Discussion}

To identify the mechanisms underlying cell growth inhibition triggered by liganded-ER $\alpha$ in ERnegative breast cancer cells, we have analyzed cell cycle distribution and gene expression changes. Our results suggest that cycle cycle blockage in $\mathrm{G} 2 / \mathrm{M}$ phase occurs, which is concomittant with an up-regulation of p21, p27, TOB and cyclin G2 levels, a down-regulation of STK1 expression and a dephosphorylation of pRb. p21, p27, TOB and cyclin G2 have been shown to inhibit proliferation [13-15], whereas STK1 overexpression could increase proliferation [16]. The down regulation of Gadd45 which expression is frequently increased in growtharrested cells and regulated by BRCA-1 [17] might be explained by the down-regulation of BRCA-1 we observed previously in such infected cells [18]. On the other hand, apoptosis is also likely to occur as shown by appearance of a subG1 peak, induction of pro-apoptotic BNIP3 [19] 
and down-regulation of DAP-3 [20]. It is also interesting to note that several oncogenes such as c-myc, c-fms, c-jun, Fra-1, Axl, or transcription factors such as ATF-2, ATF4, HIP116, CNBP or Y box are down regulated. All these proteins are generally promoting tumorigenesis [21-26]. Abnormal expression of c-fms, Axl, members of AP-1 family, CNBP (which stimulates c-myc promoter activity) or Y-box protein by malignant cells is correlated with poor prognosis [2125,27]. Down regulation of Topoisomerase II $\alpha$, HHR23A, HHR23B, DBI/ACBP and to a lesser extent of DNA-PK suggests that reintroduction of ER $\alpha$ in MDA-MB-231 cells leads to a decreased efficiency of DNA repair [28-30], which could eventually lead to apoptosis. In addition to the weaker ability of the cells, to defend themselves against DNA damage, it is likely that the cells are also losing their ability to respond to stress signals as shown by downregulation of HSP60, glutathione peroxidase and glutathione reductase [31,32]. Changes in integrin and BMP-4 $[33,34]$ could also account for the previously observed inhibition of invasion observed after reintroduction of ER $\alpha$ [9]. Other events such as down regulation of thrombin receptor, up-regulation of thrombomodulin could also account for the decreased invasiveness of these cells [35-37]. In addition, the down regulation of CTGF, which is promoting angiogenesis [38], suggests that $\mathrm{ER} \alpha$ exogenous expression could reduce the angiogenesis events during tumor formation. It is also interesting to note that, the majority of the genes regulated by E2 that we discovered, have not been previously identified as potential targets of ER, confirming the importance of our screen.

In conclusion, our data suggest that reintroduction of $\mathrm{ER} \alpha$ in ER-negative breast cancer cells could be a valuable strategy to limit their growth and their invasion. This is also concomitant to a reduced ability to repair damaged DNA and to response to stress signals, which further suggests that the cells are more likely to lose their advantages over normal cells. 


\section{Acknowledgements}

We thank the Vector Core of the University Hospital of Nantes supported by the Association Française contre les Myopathies (AFM) for the production of Adenovirus. This work was supported by grants from ARC (Association pour la Recherche contre le Cancer, Grant No. 4302), la Ligue Nationale contre le Cancer (Comite du Gard), INSERM, Associazione Italiana per la Ricerca sul Cancro (Grants 2001-02), Min. Istruzione, Università e Ricerca of Italy (Grants PRIN 2002067514_002 and FIRB RBNE0157EH_001). We are grateful to C. Duperray for his help in FACS studies.

\section{Footnote}

Present address of S. Caporali: Dermopatico dell'Immacolata, Via dei Monti di Creta 104, 00167 Roma

\section{Bibliography}

[1] Kelsey, J.L. and Berkowitz, G.S. (1988) Cancer Res 48, 5615-23.

[2] Roger, P., Sahla, M.E., Makela, S., Gustafsson, J.A., Baldet, P. and Rochefort, H. (2001) Cancer Res 61, 2537-2541.

[3] Santen, R., Manni, A., Harvey, H. and Redmond, C. (1990) Endocr. Rev. 11, 221-265.

[4] Jordan, V.C., Jeng, M.H., Catherino, W.H. and Parker, C.J. (1993) Cancer 71, 1501-1505.

[5] Dickson, R.B. and Lippman, M.E. (1995) Endocr Rev 16, 559-89.

[6] Osborne, C.K., Hobbs, K. and Clark, G.M. (1985) Cancer Res 45, 584-90.

[7] McGuire, W.L. (1975) Cancer 36, 638-44.

[8] Jiang, S.Y. and Jordan, V.C. (1992) J Natl Cancer Inst 84, 580-91.

[9] Platet, N., Cunat, S., Chalbos, D., Rochefort, H. and Garcia, M. (2000) Mol Endocrinol 14, 9991009.

[10] Garcia, M., Derocq, D., Freiss, G. and Rochefort, H. (1992) Proc Natl Acad Sci U S A 89, 1153842.

[11] Lazennec, G., Bresson, D., Lucas, A., Chauveau, C. and Vignon, F. (2001) Endocrinology 142, 4120-30.

[12] Abbondanza, C., de Falco, A., Nigro, V., Medici, N., Armetta, I., Molinari, A.M., Moncharmont, B. and Puca, G.A. (1993) Steroids 58, 4-12.

[13] Craig, C. et al. (1997) Oncogene 14, 2283-9.

[14] Tian, Y.L., Liu, F.R., Liu, J., Jiang, L., Luo, Y. and Zhang, X. (2002) Ai Zheng 21, 577-81.

[15] Jin Cho, S., La, M., Ahn, J.K., Meadows, G.G. and Joe, C.O. (2001) Biochem Biophys Res Commun 283, 273-7.

[16] Carow, C.E. et al. (1996) Blood 87, 1089-96.

[17] Mullan, P.B. et al. (2001) Oncogene 20, 6123-31.

[18] Lazennec, G. and Katzenellenbogen, B.S. (1999) Mol Cell Endocrinol 149, 93-105.

[19] Chen, G. et al. (1999) J Biol Chem 274, 7-10.

[20] Mariani, L. et al. (2001) Clin Cancer Res 7, 2480-9.

[21] Berclaz, G., Altermatt, H.J., Rohrbach, V., Kieffer, I., Dreher, E. and Andres, A.C. (2001) Ann Oncol 12, 819-24. 
[22] Kacinski, B.M. et al. (1991) Oncogene 6, 941-52.

[23] Shaulian, E. and Karin, M. (2001) Oncogene 20, 2390-400.

[24] Shimizu, K., Chen, W., Ashique, A.M., Moroi, R. and Li, Y.P. (2003) Gene 307, 51-62.

[25] Oda, Y. et al. (2003) J Pathol 199, 251-8.

[26] Hermeking, H. (2003) Curr Cancer Drug Targets 3, 173-5.

[27] Bamberger, A.M., Methner, C., Lisboa, B.W., Stadtler, C., Schulte, H.M., Loning, T. and MildeLangosch, K. (1999) Int J Cancer 84, 533-8.

[28] Sugasawa, K., Masutani, C., Uchida, A., Maekawa, T., van der Spek, P.J., Bootsma, D., Hoeijmakers, J.H. and Hanaoka, F. (1996) Mol Cell Biol 16, 4852-61.

[29] Villman, K., Stahl, E., Liljegren, G., Tidefelt, U. and Karlsson, M.G. (2002) Mod Pathol 15, 486-91.

[30] Pucci, S. et al. (2001) Oncogene 20, 739-47.

[31] Perquin, M., Oster, T., Maul, A., Froment, N., Untereiner, M. and Bagrel, D. (2000) Cancer Lett 158, 7-16.

[32] Cornford, P.A. et al. (2000) Cancer Res 60, 7099-105.

[33] van den Wijngaard, A., Mulder, W.R., Dijkema, R., Boersma, C.J., Mosselman, S., van Zoelen, E.J. and Olijve, W. (2000) Mol Endocrinol 14, 623-33.

[34] Morini, M. et al. (2000) Int J Cancer 87, 336-42.

[35] Kim, S.J. et al. (1997) Anticancer Res 17, 2319-23.

[36] Fujiwara, M., Jin, E., Ghazizadeh, M. and Kawanami, O. (2002) Pathol Int 52, 204-13.

[37] Rudroff, C. et al. (2002) Clin Exp Metastasis 19, 181-9.

[38] Kondo, S., Kubota, S., Shimo, T., Nishida, T., Yosimichi, G., Eguchi, T., Sugahara, T. and Takigawa, M. (2002) Carcinogenesis 23, 769-76.

\section{Legends to Figures}

\section{Fig. 1. ER $\alpha$ blocks cell cycle}

Ad5 or Ad-hER $\alpha$ infected MDA-MB 231 cells which had been treated for 0, 4, 24 or 48h with E2 $10^{-8} \mathrm{M}$ were analyzed by FACS for cell cycle distribution. A. Representative profiles of FACS analysis. B. Quantification of cell cycle distribution.

\section{Fig. 2. Modulation of cell cycle regulatory factors by ER $\alpha$}

WCE from Ad5 or Ad-hER $\alpha$ infected MDA-MB 231 cells which had been treated for 0 to 48h with E2 $\left(10^{-8} \mathrm{M}\right)$ were used for determination of the expression of ER $\alpha$, Erk, cyclin D1, cyclin D3, cyclin E, cyclin A, p21 ${ }^{\mathrm{CIP}-1}, \mathrm{p} 27^{\mathrm{Kip}-1}, \mathrm{cdk} 2$, cdc2 and pRb by western blot.

\section{Fig. 3: Analysis of a subset of genes regulated by $\mathrm{ER} \alpha$ in MDA-MB-231 cells}

The expression of Cyclin G2 DNA-PK, Fra-1, Gadd45, G-CSF, IL1 $\beta$, DAP-3, Macmarcks, BNIP3, p2 $1^{\text {CIP-1 }}$, TGF $\alpha$, TopoII $\alpha$ and pS2 was analyzed by northern blot using RNA form Ad5 or Ad-hER $\alpha$ infected MDA-MB-231 cells, treated or not for 48h with E2. 
Licznar et al.

Table 1: Genes up-regulated by E2 in Ad-hER $\alpha$ infected MDA-MB-231 cells

Table 2: Genes down-regulated by E2 in Ad-hER $\alpha$ infected MDA-MB-231 cells 
A

Ad5
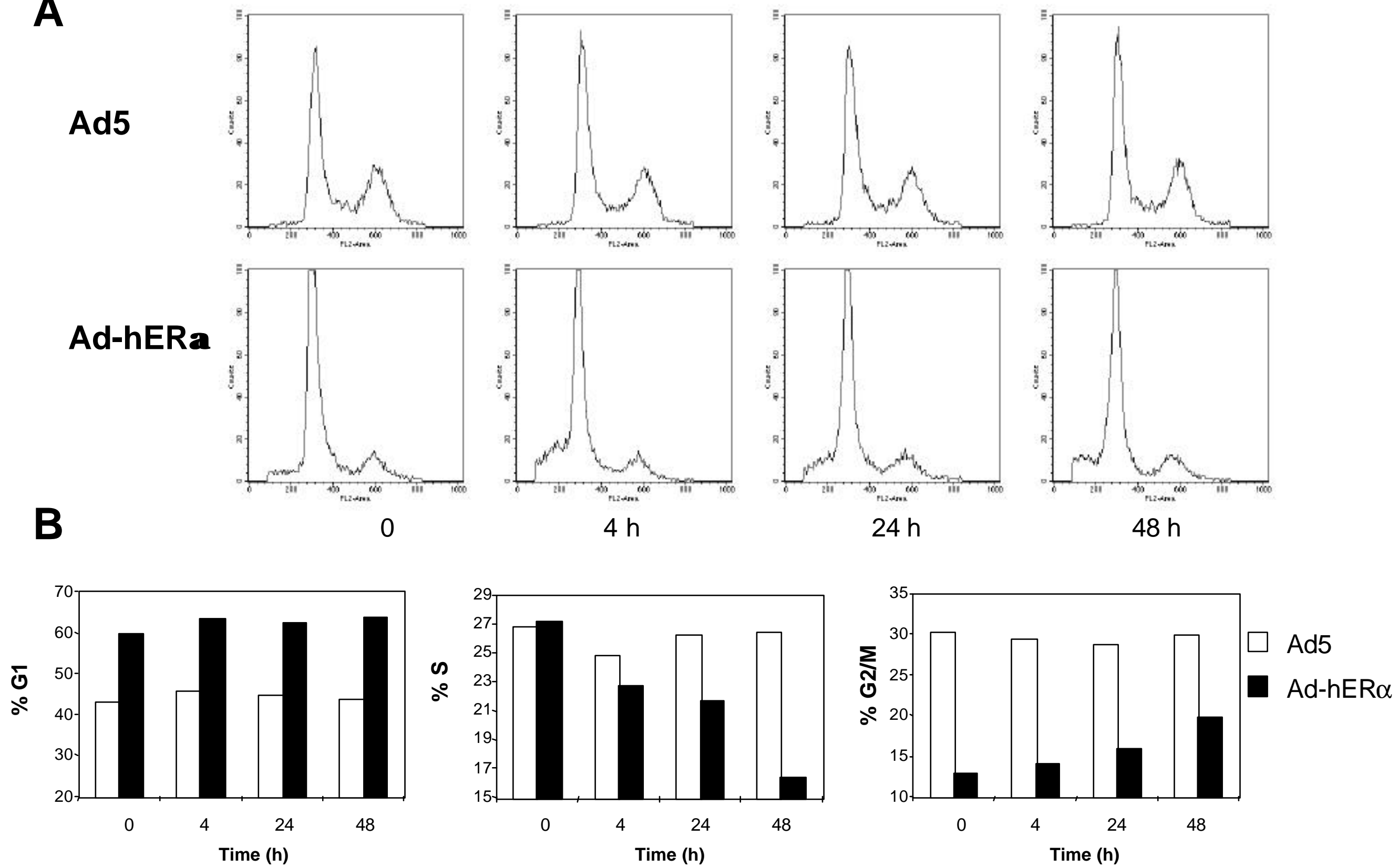

Fig. 1 


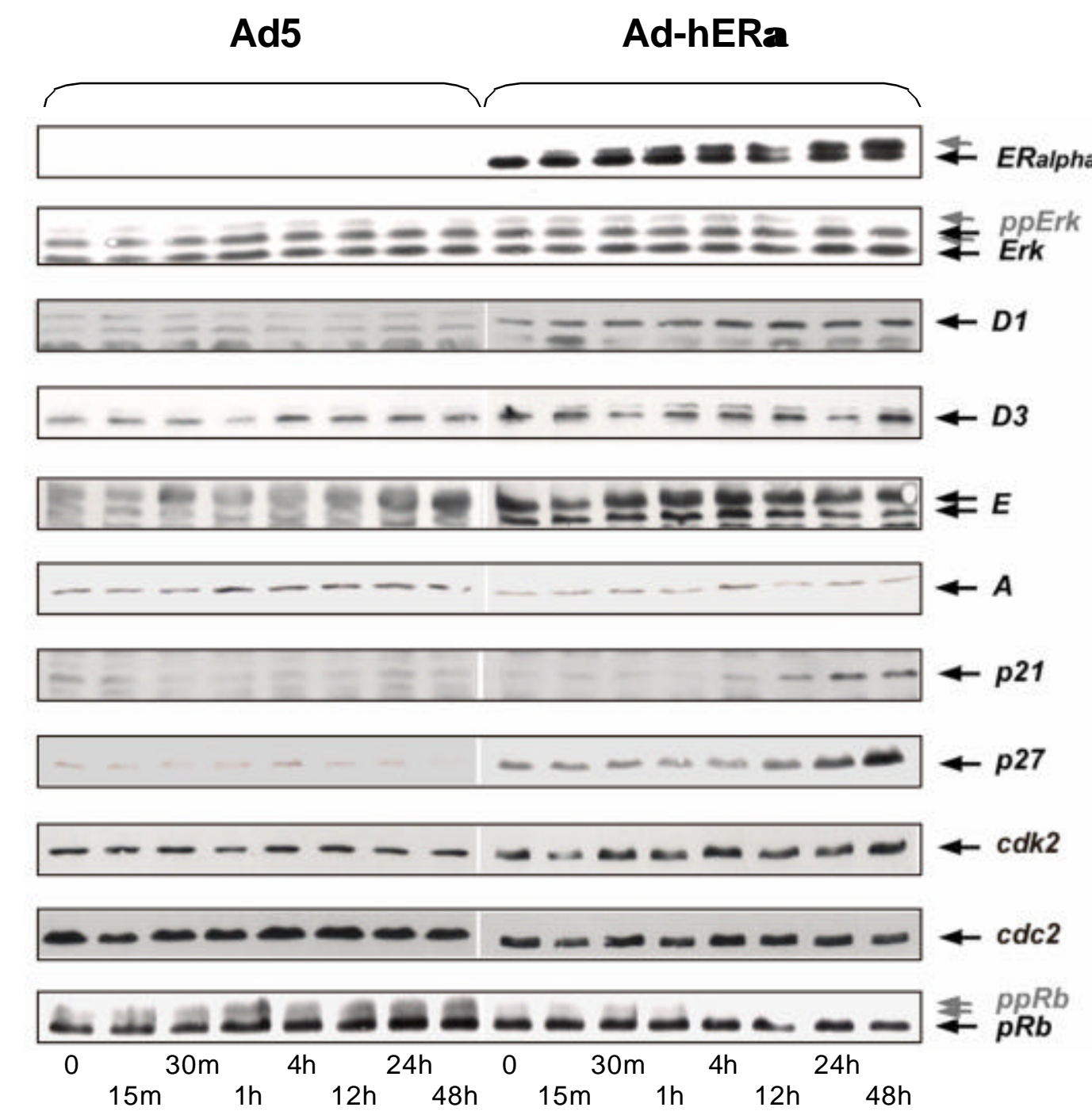

Fig. 2 


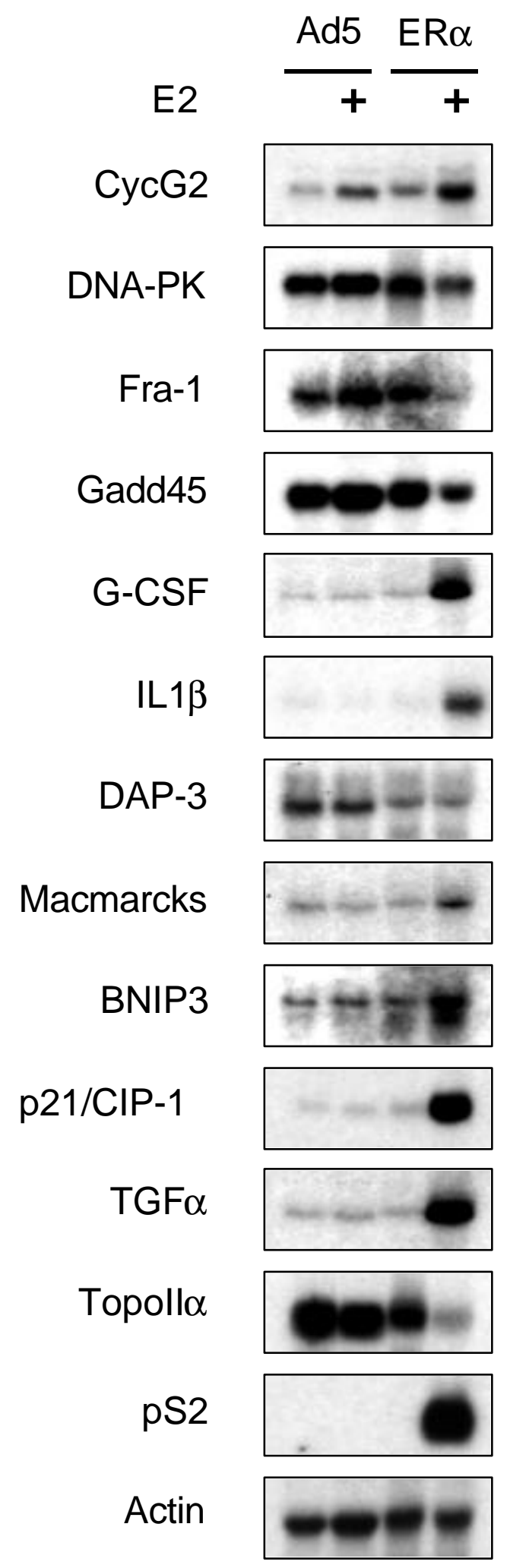

Fig. 3 
Table 1: Genes induced by E2

GenBank accession number

Gene Name

Putative Function

\section{X03484}

$\mathrm{U} 47414$

D38305

U15174

S40706

U09579

U30504

K03222

X03438

M16552

D30751

K02770
RAF

CYCLIN G2

TOB

BNIP3

GADD153

p21/CIP-1

TAFII31

TGF $\alpha$

G-CSF

Thrombomodulin

BMP-4

IL-1 $\beta$

Oncogenes - Tumor suppressors / Intracellular Kinase network members

Cell Cycle / Cyclins

Cell Cycle / Adaptators and receptor- associated proteins

Apoptosis / BCL2 family proteins

Apoptosis / DNA damage

Cell Cycle / CDK inhibitors

Transcription / RNA Polymerase

Cell signalling - extracellular communication proteins / Growth Factors

Cell signalling - extracellular communication proteins / Cytokines

Cell signalling - extracellular communication proteins / Growth Factors

Cell signalling - extracellular communication proteins / Growth Factors

Cell signalling - extracellular communication proteins / Cytokines 
V00568

X03663

J04111

$\mathrm{X} 16707$

M76125

U02687

M62424

M31630

X70326

M34664

$\mathrm{X} 15722$

M21304

$\mathrm{U} 18321$

J04088

D21235

D21090

M60974

U35835

L34673

D90209

M28372

M83234

M59911

X07979

M92934

M14200

M31159 c-myc

c-fms

c-jun

FRA-1

Axl

STK-1

Thrombin Receptor

ATF-2

Macmarcks

HSP60

Glutathione Reductase

Glutathione Peroxidase (GPX1)

DAP-3

TopoII $\alpha$

HHR23A

HHR23B

Gadd45

DNA-PK

HIP116

ATF-4

CNBP

Y-box protein

Integrin $\alpha-3$ chain

Integrin $\beta 1$ subunit

CTGF

DBI/ACBP

IGFBP-3
Oncogenes - Tumor suppressors / Transcription activators and repressors

Oncogenes - Tumor suppressors / Intracellular transducers

Oncogenes - Tumor suppressors / Transcription activators and repressors

Oncogenes - Tumor suppressors / Transcription activators and repressors

Oncogenes - Tumor suppressors / Intracellular transducers

Cell cycle / Intracellular transducers

Intracellular transducers / Growth factor receptors

Transcription activators and repressors / Intracellular transducers

Intracellular transducers / Kinase activators and inhibitors

Stress response proteins / Heat shock proteins

Stress response proteins / Xenobiotic transporters

Stress response proteins / Xenobiotic transporters

Apoptosis

DNA synthesis - Recombination and repair / Topoisomerases

DNA synthesis - Recombination and repair / Nucleotide excision repair

DNA synthesis - Recombination and repair / Nucleotide excision repair

Apoptosis / DNA synthesis - Recombination and repair

DNA synthesis - Recombination and repair / Stress response proteins

Transcription / Basic transcription factors

Transcription / Transcription activators and repressors

Transcription / Basic transcription factors

Transcription / Basic transcription factors

Cell adhesion proteins / Cell-cell adhesion receptors

Cell adhesion proteins / Cell-cell adhesion receptors

Cell signalling - extracellular communication proteins / Growth factors

Metabolism / Nucleotide metabolism

Cell signalling - extracellular communication proteins / Hormones 